\title{
Analisis Faktor yang Berhubungan dengan Status Gizi Balita di Kelurahan Limau Manis Selatan Wilayah Kerja Puskesmas Pauh Kota Padang
}

\author{
Gusrianti ${ }^{1}$, Nizwardi Azkha², Hafni Bachtiar ${ }^{3}$
}

\begin{abstract}
Abstrak
Status gizi anak balita dapat digunakan sebagai indikator keadaan gizi masyarakat. Status gizi dapat diketahui melalui prevalensi gizi anak umur 1-5 tahun karena golongan umur tersebut paling rentan terhadap gangguan gizi. Pada tahun 2013 Kecamatan Pauh menempati urutan ke-2 dari 20 Puskesmas dengan angka kejadian gizi buruk dan gizi kurang tertinggi di Kota Padang. Tujuan: Menganalisis faktor yang berhubungan dengan status gizi balita di wilayah kerja Puskesmas Pauh. Metode: Penelitian ini menggunakan pendekatan mix method, pendekatan kuantitatif dengan desain studi cross sectional dengan sampel 95 balita di wilayah kerja Puskesmas Pauh, analisis data menggunakan univariat dalam bentuk distribusi frekuensi dan bivariat menggunakan uji Chi-square. Pendekatan kualitatif dengan indepth interview kepada enam informan yang terdiri dari Lurah, Pimpinan Puskesmas, Petugas KIA, Petugas Gizi, Bidan Desa dan Kader di wilayah kerja Puskesmas Pauh. Hasil: Penelitian ini menunjukkan 23,2\% balita mengalami kurang gizi. Faktor yang memiliki hubungan bermakna dengan status gizi balita adalah pola asuh $(p=0,021)$, asupan makanan $(p=0,014)$ dan tingkat pendapatan $(p=0,043)$. Simpulan: Informasi kepada ibu terkait pola asuh yang efektif dan asupan makanan bergizi dan berimbang untuk balita guna meningkatkan status gizi balita yang baik melalui kegitan rutin Posyandu.
\end{abstract}

Kata kunci: status gizi balita, pola asuh, asupan makanan

\section{Abstract}

The nutritional status of children under five is used as an indicator of community nutrition. It is known through the nutritional prevalence of children aged 1-5 years because the age group is most vulnerable to nutrition. In 2013, Pauh Subdistrict ranked second out of 20 Puskesmas with the highest levels of malnutrition and malnutrition in Padang City. Objectives: To analized factors that had relationship with the nutritional status of children under five in the Pauh Puskesmas work area. Methods: This study used a mixed method, quantitative research with cross sectional study design with a sample of 95 toddlers in the work area of Pauh Health Center, data analysis using univariate in the form of frequency distribution and bivariate using Chi-square test. For interviews with 6 informants consisting of the Lurah, Puskesmas Leaders, MCH Officers, Nutrition Officers, Village Midwives and Cadres in the Pauh Puskesmas work area. Results: There were $23.2 \%$ of children under five that had malnutrition. The factors that had a relationship with the nutritional status of children under five were parenting $(p=0.021)$, food intake $(p=0.014)$ and income level ( $p=$ 0.043). Conclusion: Information to mothers regarding effective parenting and balanced and nutritious food intake for toddlers to improve the nutritional status of toddlers through routine Posyandu activities.

Keywords: toddler nutritional status, parenting, food intake

Affiliasi penulis: 1. Sekolah Tinggi IImu Kesehatan Alifah Padang, 2. Fakultas Kesehatan Masyarakat Universitas Andalas Padang, 3. Bagian IImu Kesehatan Masyarakat Fakultas Kedokteran Universitas Andalas Padang
Korespondensi: Gusrianti, Email: gusrianti819@gmail.com, $\mathrm{Hp}: 081363544657$ 


\section{PENDAHULUAN}

Status gizi (Nutriens) adalah ikatan kimia yang diperlukan tubuh untuk melakukan fungsinya yaitu menghasilkan energi, membangun dan memelihara jaringan serta mengatur proses-proses kehidupan. ${ }^{1}$

Status gizi anak balita menurut Santoso dan Ranti (2004) menggambarkan keadaan tubuh anak tersebut yang erat hubungannya dengan konsumsi, penyerapan dan pemanfaatan zat gizi yang terkandung didalam makanan serta keadaan kesehatannya. Status gizi anak balita dapat digunakan sebagai indikator keadaan gizi masyarakat dan dapat diketahui melalui prevalensi gizi anak umur 1-5 tahun 1-5 tahun, karena golongan umur tersebut paling rentan terhadap gangguan gizi dan sangat tergantung terhadap makanan yang diberikan kepada mereka. ${ }^{2}$

Laporan UNICEF tahun 2006 jumlah balita gizi buruk di Indonesia berjumlah 2,3 juta jiwa, kasus gizi buruk meningkat sekitar 500.000 jiwa dibandingkan dengan data tahun 2004/2005 sejumlah 1,8 juta jiwa. Tahun 2004 Indonesia dengan urutan ke 111 untuk indeks pembangunan manusia (Human Development Index/ HDI) dari 177 negara yang dinilai. Angka ini jauh lebih rendah dari pada Malaysia (59), Thailan (76), atau Filipina (73). Rendahnya HDI mencerminkan bahwa tingkat pendidikan, kesehatan dan pendapatan perkapita penduduk Indonesia masih rendah, masalah ini sangat erat kaitannya dengan keadaan gizi penduduk. $^{3}$

Hasil penelitian Djola (2011) menunjukkan bahwa prevalensi gizi kurang pada balita dibawah tiga tahun menurun secara signifikan terhadap pendapatan keluarga meningkat. ${ }^{4}$ Menurut Sarah (2011) bahwa penghasilan keluarga akan turut menentukan hidangan yang disajikan keluarga sehari-hari, makanan yang berkualitas sangat diperlukan oleh balita untuk memperoleh kebutuhan zat gizi yang cukup, kelangsungan hidup, pemulihan kesehatan susudah sakit, aktivitas, pertumbuhan dan perkembangan. ${ }^{5}$

Laporan Tahunan Dinas Kesehatan Kota Padang pada tahun 2013 dilakukan survey Pemantauan Status Gizi (PSG) dan penimbangan massal diseluruh kelurahan Wilayah Kerja Puskesmas yang berada di Kota Padang. Jumlah sampel sebanyak 52.379 balita, dengan hasil pemantauan status gizi (PSG) dan penimbangan massal balita prevalensi balita gizi kurang dengan indikator BB/U sebesar $10,68 \%{ }^{6}$

Berdasarkan data Laporan Dinas Kesehatan Kota Padang tahun 2013, dari beberapa Puskesmas yang ada di Kota Padang. Salah satunya Puskesmas Pauh termasuk dalam kecamatan yang rawan gizi dimana prevalensi gizi buruk dan gizi kurangnya menurut indeks BB/U besar dari $20 \%$ yaitu jumlahnya $22.36 \%{ }^{6}$

Kecamatan Pauh pada tahun 2013 menempati urutan ke-2 dari 20 Puskesmas angka kejadian gizi buruk dan gizi kurang tertinggi di Kota Padang. ${ }^{6}$ Dari data awal yang peneliti dapatkan dari Laporan Tahunan Puskesmas Pauh Tahun 2012 dengan sampel sebanyak 300 balita diketahui status gizi kurang sebanyak 52 balita (17,33\%) dan balita dengan status gizi buruk sebanyak 16 balita $(5,33 \%),{ }^{7}$ dan di tahun 2013 angka gizi kurang juga menempati urutan tertinggi, yaitu 66 orang (22\%) dan gizi lebih 21 anak $(7 \%)^{8}$

Berdasarkan survey pendahuluan dari laporan Puskesmas Pauh memiliki 9 kelurahan, jumlah anak balita terbanyak yang mengalami status gizi kurang yaitu Kelurahan Limau Manis Selatan (LMS), dari 39 anak balita yang disurvei terdapat 6 anak balita gizi kurang dan 1 orang gizi buruk dengan indek BB/U. Hasil pemantauan status gizi kurang di LMS pendapatan keluarga sangat bervasiari ada Petani, Swasta, PNS, Buruh dan lain-lain. Penelitian ini bertujuan menganalisis faktor yang berhubungan dengan status gizi balita di wilayah kerja Puskesmas Pauh.

\section{METODE}

Penelitian ini menggunakan pendekatan mix method yaitu kombinasi pendekatan kuantitatif dan kualitatif. Pengumpulan data dilakukan dari bulan oktober sampai dengan november 2016 di wilayah kerja Puskesmas Pauh di Kota Padang.

Populasi dalam penelitian ini adalah semua anak balita yang tercatat di wilayah kerja Puskesmas Pauh di Kota Padang dan sampel sebanyak 95 balita berdasarkan perhitungan menggunakan rumus 
Sastroasmoro. Kriteria inklusi dari responden yaitu ibu dan anak balita usia 1-5 tahun Kelurahan Limau Manis Selatan Wilayah Kerja Puskesmas Pauh Kota Padang. Pengambilan sampel dilakukan dengan menggunakan teknik cluster sampling.

Informan dalam penelitian ini berjumlah enam orang yaitu Lurah, Pimpinan Puskesmas, Petugas KIA, Petugas Gizi, Bidan Desa dan Kader di wilayah kerja Puskesmas Pauh. Pengumpulan data kuantitatif dilakukan dengan cara menyebarkan kuesioner kepada sampel, sedangkan pengumpulan data kualitatif dilakukan dengan cara wawancara mendalam, observasi, dan telaah dokumen.

Analisis data kuantitatif menggunakan analisis univariat dalam bentuk distribusi frekuensi dan analisis bivariate menggunakan chi square. Analisis data kualitatif dilakukan dengan metode triagulasi. Langkah dalam melakukan analisis data kuantitatif terdiri dari editing, coding, entry, cleaning, dan output sedangkan dalam menganalisis data kualitatif terdari dari mereduksi data, menyajikan data, penarikan kesimpulan dan verifikasi.

\section{HASIL}

Adapun karakteristik responden dalam penelitian ini dapat dilihat dari Tabel 1.

Tabel 1. Distrubusi frekuensi karakteristik responden

\begin{tabular}{|c|c|c|}
\hline Karekteristik & $\begin{array}{c}f \\
(n=95)\end{array}$ & $\%$ \\
\hline \multicolumn{3}{|l|}{ Status Gizi } \\
\hline Gizi Kurang & 22 & 23,2 \\
\hline Gizi Baik & 73 & 76,8 \\
\hline \multicolumn{3}{|l|}{ Pola Asuh } \\
\hline Tidak Efektif & 63 & 66,3 \\
\hline Efektif & 32 & 33,7 \\
\hline \multicolumn{3}{|l|}{ Asupan Makanan } \\
\hline Kurang baik & 37 & 38,9 \\
\hline Baik & 58 & 61,1 \\
\hline \multicolumn{3}{|l|}{ Pekerjaan Ibu } \\
\hline Tidak Bekerja & 89 & 93,7 \\
\hline Bekerja & 6 & 6,3 \\
\hline \multicolumn{3}{|l|}{ Pendidikan } \\
\hline Rendah & 37 & $39,0 \%$ \\
\hline Tinggi & 58 & $61,0 \%$ \\
\hline \multicolumn{3}{|l|}{ Pendapatan Keluarga } \\
\hline Rendah & 49 & 51,6 \\
\hline Tinggi & 46 & 48,4 \\
\hline \multicolumn{3}{|c|}{ Riwayat Penyakit Diare } \\
\hline $\mathrm{Ya}$ & 16 & 16,8 \\
\hline Tidak & 79 & 83,2 \\
\hline
\end{tabular}

Pada Tabel 1 dapat dilihat bahwa sebagian besar status gizi balita baik (76,8 \%), lebih dari separoh pola asuh ibu terhadap balita tidak efektif $(66,3 \%)$, lebih dari separoh asupan makanan balita baik $(61,1 \%)$, pada umum nya ibu balita tidak bekerja $(93,7 \%)$, lebih dari separoh $(61 \%)$ tingat pendidikan tinggi, lebih dari separoh pendapatan keluarga rendah $(51,6 \%)$, Sebagian besar balita tidak pernah menderita penyakit diare $(83,2 \%)$ dalam tiga bulan terakhir.

Tabel 2. Faktor yang berhubungan dengan status giizi balita

\begin{tabular}{|c|c|c|c|c|c|}
\hline \multirow{3}{*}{ Variabel } & \multicolumn{4}{|c|}{ Status Gizi } & \multirow{3}{*}{$\mathbf{P}$} \\
\hline & \multicolumn{2}{|c|}{ Gizi Kurang } & \multicolumn{2}{|c|}{ Gizi Baik } & \\
\hline & $f$ & $\%$ & $f$ & $\%$ & \\
\hline \multicolumn{6}{|c|}{ Status Pekerjaan } \\
\hline Tidak & 19 & 213 & 70 & 787 & \multirow{3}{*}{0,135} \\
\hline Bekerja & (5) & 21,0 & 10 & $r, r$ & \\
\hline Bekerja & 3 & 50,0 & 3 & 50,0 & \\
\hline \multicolumn{6}{|l|}{ Pendidikan } \\
\hline Rendah & 6 & 16,2 & 31 & 83,8 & \multirow{2}{*}{0,302} \\
\hline Tinggi & 16 & 27,6 & 42 & 72,4 & \\
\hline \multicolumn{6}{|l|}{ Pola Asuh } \\
\hline Tidak efektif & 20 & 31,7 & 43 & 68,3 & \multirow{2}{*}{0,021} \\
\hline Efektif & 2 & 6,3 & 30 & 93,8 & \\
\hline \multicolumn{6}{|c|}{ Asupan Makanan } \\
\hline Tidak Baik & 14 & 37,8 & 23 & 62,2 & \multirow{2}{*}{0,014} \\
\hline Baik & 8 & 13,8 & 50 & 86,2 & \\
\hline \multicolumn{6}{|c|}{ Riwayat Penyakit Diare } \\
\hline Ya & 2 & 8,3 & 14 & 87,5 & \multirow{2}{*}{0,346} \\
\hline Tidak & 20 & 25,3 & 59 & 74,7 & \\
\hline \multicolumn{6}{|c|}{ Tingkat Pendapatan } \\
\hline Rendah & 16 & 32,7 & 33 & 67,3 & \multirow{2}{*}{0,043} \\
\hline Tinggi & 6 & 13,0 & 40 & 87,0 & \\
\hline
\end{tabular}

Hasil analisis bivariat dengan uji chi-square pada Tabel 2 didapatkan bahwa faktor yang memiliki hubungan bermakna dengan status gizi balita adalah adalah pola asuh $(p=0,021)$, asupan makanan $(p=0,014)$ dan tingkat pendapatan $(p=0,043)$. Status perkerjaan, pendidikan dan riwayat penyakit diare tidak memiliki hubungan bermakna dengan status gizi balita.

Berdasarkan hasil wawancara mendalam, perencanaan kesehatan gizi balita diawali dari screening balita di Kelurahan Limau Manis Selatan. 
Kegiatan yang dilakukan yaitu melalui pengukuran status gizi, penyuluhan, edukasi dan pemberian makanan tambahan melalui kegiatan Posyandu. Pengorganisasian kegiatan gizi balita ini dibentuk oleh bagian KIA tersebut, dimana mencakup didalamnya adalah petugas gizi, penanggung jawab posyandu (bidan), petugas kesehatan (membantu) bidan desa, kader dan dari kelurahan. Hambatan dalam upaya pencegahan gizi kurang pada balita yaitu merubah kebiasaan yang relatif sulit seperti dating keposyandu tiap bulan untuk, mengukur berat badan dan tinggi badan. Harapan dalam pengorganisasian ini yaitu untuk dapat menurunkan angka gizi kurang pada balita dan adanya kerjasama yang baik antara masyarakat, perangkat lurah dan puskesmas.

Pelaksanaan pemantauan dan pencegahan kurang gizi dilakukan setiap bulannya melalui posyandu balita. Kegiatan posyandu balita adalah bentuk kontrol dari status gizi balita di setiap daerah, sumber daya manusia untuk posyandu ini sudah cukup diantaranya bidan penanggung jawab posyandu, dibantu tenaga kesehatan beberapa orang dan beberapa kader.

Evaluasi yang dilakukan puskesmas dalam upaya pencegahan gizi kurang pada balita terlihat dari berkesinambungannya kegiatan posyandu yang dilakukan tiap bulan dilengkapi dengan laporan kegiatan. Monitoring juga dilakukan oleh pimpinan untuk terjun langsung melihat kegiatan posyantu tersebut. Partisipasi dari kelurahan juga bentuk dari monitoring dan evaluasi yang dilakukan berkesinambungan.

\section{PEMBAHASAN}

Status gizi adalah keadaan tubuh sebagai akibat konsumsi makanan dan penggunaan zat gizi. Dibedakan antara status gizi buruk, kurang, baik, dan lebih. ${ }^{9}$ Status gizi adalah keadaan tubuh yang merupakan hasil akhir dari keseimbangan antara zat gizi yang masuk ke dalam tubuh. ${ }^{10}$ Hasil penelitian didapatkan bahwa dari 95 orang balita terdapat 76,8 \% balita status gizi baik dan 22 balita (23,2\%) dengan status gizi kurang. Hasil penelitian yang sama ditemukan oleh Lubis (2008) yaitu 63,9 \% dengan status gizi Baik dibandingkan dengan status gizi kurang dan gizi buruk. ${ }^{11}$ Penelitian ini berbeda dengan yang dilakukan oleh Djola (2011) yaitu 57\% dari responden yang diteliti dengan gizi kurang dan $43 \%$ dengan status gizi baik. ${ }^{4}$ Hasil penelitian ini menunjukkan bahwa di kelurahan Limau Manis selatan masih banyak balita dengan status gizi kurang.

\section{Hubungan pola asuh dengan status gizi balita di wilayah kerja Puskesmas Pauh Kota Padang}

Terdapat hubungan yang bermakna antara pola asuh dengan status gizi balita $(p=0,021)$. Pola asuh adalah praktek dirumah tangga yang diwujudkan dengan tersedianya pangan dan perawatan kesehatan serta sumber lainnya untuk kelangsungan pangan, pertumbuhan dan perkembangan anak. Pola asuh yang baik akan mempengaruhi keadaan kesehatan dan keadaan gizi pada anak. ${ }^{5}$

Pola pengasuhan merupakan cara orang tua dalam mendidik anak dan membesarkan anak dipengaruhi oleh banyak faktor budaya, agama, kebiasaan serta kepribadian orang tua. Pengasuhan merupakan faktor yang erat kaitannya dengan pertumbuhan dan perkembangan anak berusia dibawah lima tahun. Masa anak usia 1-5 tahun (balita) adalah dimana masa dimana anak masih sangat membutuhkan suplai makanan dan gizi dalam jumlah yang memadai. Pada masa ini juga, anak-anak masih sangat tergantung pada perawatan dan pengasuhan ibunya. ${ }^{5}$

Seseorang ibu memegang peranan penting dalam pengasuhan anaknya. Pola pengasuhan pada tiap ibu berbeda karena dipengaruhi oleh faktor yang mendukung, antara lain: latar belakang pendidikan ibu, jumlah anak dan sebagainya. Banyak penyelidik berpendapat bahwa status pendidikan ibu sangat berpengaruh terhadap kualitas pengasuhnya. Pendidikan ibu yang rendah masih sering ditemui, semua hal tersebut sering menyebabkan penyimpangan terhadap keadaan tumbuh kembang dan status gizi anak terutama pada anak usia balita. ${ }^{5}$

Hasil penelitian yang berbeda ditemukan oleh Nurul (2010) dimana menemukan lebih dengan pola asuh baik 42 (82,4\%) dibanding yang pola asuh kurang baik. ${ }^{12}$ Hasil penelitian yang berbeda juga ditemukan oleh Lubis (2008) dimana menemukan 96\% 
responden dengan pola asuh baik dan $4 \%$ dengan pola asuh kurang baik. ${ }^{11}$ Hasil penelitian ini menunjukkan bahwa masih banyak pola asuh ibu yang kurang baik terhadap anak, sehingga secara tidak langsung mempengaruhi status gizi balita.

\section{Hubungan asupan makanan dengan status gizi balita di wilayah kerja Puskesmas Pauh Kota Padang}

Terdapat hubungan yang bermakna antara asupan makanan dengan status gizi balita $(p=0,014)$. Asupan makanan adalah semua jenis makanan yang dikonsumsi tubuh setiap hari. Asupan makanan berpengaruh terhadap status gizi seseorang. Gangguan gizi disebabkan faktor primer dan faktor sekunder. Faktor primer adalah bila susunan makanan seseorang salah dalam kualitas dan kuantitas. Faktor sekunder meliputi semua faktor yang menyebabkan zat-zat gizi tidak sampai di sel-sel tubuh setelah makanan dikonsumsi. ${ }^{9}$

Penyediaan makanan bergizi sangat penting untuk anak usia balita. Kebutuhan zat gizi pada balita harus cukup dan seimbang karena anak balita sedang mengalami proses pertumbuhan dan perkembangan yang pesat. Kebutuhan energ dan protein balita berdasarkan Angka Kecukupan Gizi. ${ }^{12}$

Hasil penelitian yang berbeda oleh Lubis (2008) yang menemukan $94 \%$ balita dengan asupan makanan yang baik dan hanya $6 \%$ dengan asupan makanan tidak baik. ${ }^{11}$ Hasil penelitian ini berbeda dengan yang ditemukan oleh Irmawati (2013) dimana $34,3 \%$ responden dengan asupan makanan yang kurang baik dab $65,7 \%$ dengan asupan makanan baik. ${ }^{13}$

\section{Hubungan tingkat pendapatan dengan status gizi balita di wilayah kerja Puskesmas Pauh Kota Padang}

Terdapat hubungan yang bermakna antara tingkat pendapatan dengan status gizi balita $(p=0,043)$. Status Ekonomi adalah Kedudukan seseorang atau keluarga dimasyarakat berdasarkan pendapatan per bulan. Status ekonomi dapat dilihat dari pendapatan yang disesuaikan dengan harga barang pokok. ${ }^{14}$
Keterbatasan penghasilan keluarga turut menentukan mutu makanan yang disajikan. ${ }^{15}$ Tidak dapat disangkal bahwa penghasilan keluarga turut menentukan hidangan yang disajikan untuk keluarga sehari-hari, baik kualitas maupun jumlah makanan. Pendapatan keluarga turut mempengaruhi gizi. ${ }^{16}$

Masalah gizi pada hakikatnya adalah masalah kesehatan masyarakat, namun penanggulangannya tidak dapat dilakukan dengan pendekatan medis dan pelayanan kesehatan saja. ${ }^{17}$ Masalah gizi merupakan sindrom kemiskinan yang erat kaitannya dengan masalah ketahanan pangan di tingkat rumah tangga dan menyangkut aspek pengetahuan serta perilaku yang mendukung pola hidup sehat. ${ }^{18}$

Masalah gizi kurang pada umumnya disebabkan oleh kemiskinan, kurangnya persedian pangan, kurang baiknya kualitas lingkungan (sanitasi), kurangnya pengetahuan masyarakat tentang gizi, menu seimbang dan kesehatan, dan adanya daerah miskin gizi (iodium), sebaliknya masalah gizi lebih disebabkan oleh kemajuan ekonomi pada lapisan masyarakat tertentu disertai dengan kurangnya pengetahun tentang gizi. ${ }^{19}$

Kemiskinan sebagai penyebab gizi kurang menduduki posisi pertama pada kondisi yang umum. Hal ini harus mendapatkan perhatian serius karena keadaan ekonomi ini relatif mudah diukur dan berpengaruh besar pada konsumsi pangan. Golongan miskin menggunakan bagian terbesar dari pendapatan untuk memenuhi kebutuhan makanan, di mana untuk keluarga-keluarga di negara berkembanga sekitar dua pertiga. ${ }^{20}$

\section{SIMPULAN}

Faktor yang berhubungan dengan status gizi balita di wilayah kerja Puskesmas Pauh di Kota Padang adalah pola asuh, asupan makanan dan tingkat pendapatan orang tua. Hal tersebut membuktikan bahwa peran orang tua terutama ibu sangat penting dalam tumbuh kembang balita yang dapat mempengaruhi status gizi balita. Adapun bentuk peran orang tua tersebut adalah dari pola asuh, menyiapkan makanan yang bergizi dan berimbang untuk balita. 
Status pendidikan ibu, pekerjaan ibu dan riwayat penyakit diare pada balita tidak memiliki hubungan bermakna pada penelitian ini.

\section{SARAN}

Melaksanakan posyandu secara rutin untuk memonitor status gizi balita sehingga dapat melakukan deteksi dini balita yang kurang gizi, sehingga dapat segera melakukan perbaikan gizi balita.

\section{UCAPAN TERIMA KASIH}

Terima kasih kepada pihak Puskesmas Pauh Kota Padang yang telah memberikan pengalaman dan pengetahuan yang bermanfaat bagi penulis. Serta pihak lain yang turut membantu dalam menyelesaikan penelitian ini.

\section{DAFTAR PUSTAKA}

1. Almatsier S. Prinsip dasar ilmu gizi. Jakarta: PT Gramedia Pustaka Utama; 2010.hlm.46-51.

2. Santoso S, Ranti AL. Kesehatan dan gizi. Jakarta: Rineka Cipta; 2004,hlm.22-4.

3. United Nations Children's Fund (UNICEF). The state of the world's children. New York: UNICEF; 2006.hlm.31.

4. Djola R. Hubungan antara tingkat pendapatan keluarga dan pola asuh dengan status gizi anak balita di desa Bongkudai kecamatan Modayang Barat [tesis]. Manado: Universitas Ratulangi; 2011.

5. Sarah M. Hubungan tingkat sosial ekonomi dan pola asuh dengan status gizi anak balita di wilayah kerja puskesmas Pantai Cermin Kecamatan Tanjung Pura Kabupaten Langka [tesis]. Medan: Universitas Sumatera Utara; 2011.

6. Dinas Kesehatan Kota Padang (DKK Padang). Laporan tahunan dinas kesehatan kota Padang tahun 2013. Padang: DKK Padang; 2013.
7. Puskesmas Pauh. Laporan tahunan puskesmas Pauh. Padang: Puskesmas Pauh; 2012.

8. Puskesmas Pauh. Laporan tahunan puskesmas Pauh. Padang: Puskesmas Pauh; 2013.

9. Almatsier S. Prinsip dasar ilmu gizi. Jakarta: PT Gramedia Pustaka Utama; 2009.hlm.41-3.

10. Cakrawati D, Mustika NH. Bahan pangan, gizi dan kesehatan. Bandung: Alfabeta. 2012.hIm.39.

11. Lubis R. Hubungan pola asuh ibu dengan status gizi anak balita di wilayah kerja puskesmas Pantai Cermin Kecamatan Tanjung Pura Kabupaten Langkat [tesis]. Medan. Universitas Sumatera Utara; 2008.

12. Nurul. Faktor-faktor yang berhubungan dengan status gizi balita 6-60 bulan di kelurahan Kuto Batu kota Palembang. Jurnal Ekologi Kesehatan. 2010; 9(3):1274-81.

13. Irmawati L. Faktor-faktor yang berhubungan dengan status gizi balita di rumah sakit daerah kabupaten Bekasi. Jurnal Kesehatan Masyarakat Nasional. 2013;7(11): 514-21.

14. Kartono. Pemimpin dan kepemimpinan. Jakarta: PT Rajagrafindo Persada; 2006.hlm.63-4.

15. Hasdianah HR. Gizi, pemanfaatan gizi, diet, dan obesitas. Yogyakarta: Nuha Medika; 2014.hlm.33.

16. Supariasa DN. Penilaian status gizi. Jakarta: EGC; 2012.hlm.82.

17. Proverawati A, Asfuah S. Buku ajar gizi untuk kebidanan. Yogyakarta: Nuha Medika. 2009:67-9.

18. Fadli A. Buku pintar anak kesehatan. Yogyakarta: Pustaka Anggrek; 2010.hlm.29.

19. Adriani M. Pengantar gizi masyarakat. Jakarta: Prenada Media. 2012.hlm.97.

20. Suhardjo. Pengaruh penerapan standar akuntansi pemerintahan dan kualitas aparatur pemerintah daerah terhadap kualitas laporan keuangan (studi kasus pada pemerintah Kota Tua). Jurnal STIE Semarang. 2013;4(2):25-35. 